\title{
Pengembangan Media Budel (Buku Berjendela) pada Tema Keluargaku
}

\author{
Niken Amanda 1*, Fine Reffiane ${ }^{2}$, Prasena Arisyanto ${ }^{3}$ \\ 123 Program Studi Pendidikan Guru Sekolah Dasar Fakultas Ilmu Pendidikan Universitas PGRI Semarang
}

\begin{abstract}
Abstrak
Keywords:

Latar belakang penelitian ini adalah penggunaan media pembelajaran yang masih rendah. Media budel (buku berjendela) dapat digunakan untuk mendukung

Pengembangan, buku berjendela, keluargaku. kegiatan pembelajaran dan meningkatkan konsentrasi belajar siswa. Tujuan penelitian ini adalah untuk mengetahui kevalidan dan kepraktisan media budel (buku berjendela) yang digunakan untuk siswa kelas I sekolah dasar. Jenis penelitian ini adalah penelitian dan pengembangan atau Research and Development (R\&D). Pengembangan media budel (buku berjendel) tema keluargaku terdiri dari enam tahapan yaitu (1) potensi dan masalah, (2) pengumpulan informasi, (3) desain produk, (4) validasi desain, (5) revisi desain, (6) uji coba produk. Penelitian ini dilaksanakan pada 3 kelas di SD Negeri Peterongan yaitu kelas IA, IB dan IC. Hasil uji kevalidan diperoleh dari penilaian ahli media sebesar 91,34\% (sangat baik) dan penilaian ahli materi sebesar 92,50\% (sangat baik). Sedangkan hasil uji kepraktisan diperoleh dari penilaian respon guru sebesar 90,67\% (sangat baik) dan penilaian respon siswa sebesar 92,82\% (sangat baik). Hasil penelitian menunjukkan bahwa siswa menyukai penggunaan media budel (buku berjendela) untuk mempermudah memahami materi dan dapat digunakan guru sebagai media alternatif mengajar. Kesimpulannya bahwa media budel (buku berjendela) yang dikembangkan oleh peneliti dengan gambar menarik dengan tambahan perekat pada tema keluargaku, valid dan praktis digunakan untuk siswa kelas I sekolah dasar.
\end{abstract}

\section{PENDAHULUAN}

Pendidikan merupakan hal yang paling penting dan mendasar bagi setiap manusia terutama bagi generasi penerus bangsa. Pendidikan dianggap sebagai salah satu cara untuk mengembangkan potensipotensi yang dimiliki setiap generasi bangsa. Menyadari hal tersebut pemerintah mengupayakan menciptakan generasi bangsa yang berkualitas melalui pendidikan seperti yang tercantum pada UU No. 20 tahun 2003 Bab 1 Pasal 1 Ayat 1, tentang sistem pendidikan nasional bahwa Pendidikan adalah usaha sadar dan terencana untuk mewujudkan suasana belajar dan proses pembelajaran agar peserta didik secara aktif mengembangkan potensi dirinya untuk memiliki kekuatan spiritual keagamaan, pengendalian diri, kepribadian, kecerdasan, akhlak mulia, serta keterampilan yang diperlukan dirinya, masyarakat, bangsa, dan negara.

Mengembangkan potensi yang dimiliki siswa agar memenuhi kriteria Undang - Undang Sistem Pendidikan Nasional Tahun 2003 Nomor 20 Pasal 1 Ayat 1 tersebut, maka diperlukan adanya kerjasama antara yang membuat kebijakan dengan yang melaksanakan pembelajaran. Pelaksana pembelajaran yang disebut dengan guru merupakan subjek yang sangat berpengaruh terhadap hasil pendidikan. Keberhasilan dalam mencapai tujuan pendidikan bukan hanya ditentukan oleh siswa, tetapi guru memegang peranan penting didalam keberhasilan suatu pembelajaran. Peranan guru sebagai pembimbing harus menghidupkan suasana belajar yang kondusif serta memberikan motivasi belajar kepeada peserta didik. Salah satunya dengan menggunakan media pembelajaran. Menurut Sanaky (2013: 4) media pembelajaran adalah sarana atau alat bantu pendidikan yang dapat digunakan sebagai perantara

* Corresponding author.

E-mail Addresses: - temanis98@gmail.com (Niken Amanda) 
dalam proses pembelajaran untuk mempertinggi efektivitas dan efisiensial dalam mencapai tujuan pengajaran. Sedangkan menurut Sadiman dalam Kustandi dkk (2011:7) mengatakan "media adalah perantara atau pengantar pesan dari pengirim kepenerima pesan". Hal ini diartikan bahwa media digunakan sebagai perantara guru dalam menyampaikan suatu materi kepada peserta didik. Media pembelajaran diharapkan dapat membantu dalam proses pembelajaran yang dapat membangkitkan motivasi belajar peserta didik, menyajikan informasi belajar dengan tampilan menarik, meningkatkan keaktifan siswa, tingkat kefokusan siswa dalam pembelajaran serta meningkatkan hasil belajar siswa.

Penggunaan media dapat membantu guru dan siswa dalam proses pembelajaran, terutama pada pembelajaran di kurikulum 2013 yaitu pembelajaran tematik. Menurut Poerwadaminta dalam Majid (2014: 80) mengatakan "Pembelajaran tematik adalah pembelajaran terpadu yang menggunakan tema untuk mengaitkan beberapa mata pelajaran sehingga dapat memberikan pengalaman bermkana kepada murid. Tema adalah pokok pikiran atau gagasan pokok yang menjadi pokok pembicaraan." Berkaitan dengan pendapat tersebut melalui pembelajaran tematik, peserta didik dapat memperoleh pengalaman bermakna. Bermakna berarti dalam proses pembelajaran berlangsung, siswa tidak hanya menghafal konsep atau fakta namun melakukan kegiatan yang menghubungkan konsep-konsep untuk menghasilkan pemahaman secara menyeluruh sehingga konsep yang dipelajari dapat dipahami secara baik dan tidak mudah dilupakan karena siswa ikut terlibat secara langsung. Oleh sebab itu, media pembelajaran merupakan bagian yang penting yang harus mendapat perhatian dari guru, kemampuan guru dalam merancang dan menerapkan media pembelajaran dan dapat menjadi kunci dari keberhasilan proses pembelajaran.

Berdasarkan hasil observasi dan wawancara yang telah dilakukan peneliti dikelas I di SDN Peterongan Semarang, pada tanggal 28 Mei 2018 didapatkan hasil bahwa guru kesulitan dalam menemukan media pembelajaran tematik yang dapat memuat beberapa aspek seperti kognitif, afektif dan psikomotor dalam pembelajaran kurikulum 2013. Selain hal itu, guru juga mengalami kesulitan ketika ada beberapa siswa yang tidak fokus pada materi yang disampaikan guru karena terlalu aktif. Kesulitan guru mengajar salah satunya dipengaruhi karena kurang tersedianya media pembelajaran tematik yang dapat membantu guru dalam mengajarkan tematik khususnya dalam mengaitkan konsep-konsep antarmata pelajaran. Selama itu guru hanya menggunakan buku teks yang sudah tersedia. Padahal buku teks tematik yang digunakan oleh guru masih terdapat banyak kekurangan. Buku teks yang seharusnya membantu guru dalam mengajarkan tematik justru merepotkan guru untuk mencari penguatan materi lain. Kurangnya waktu pembelajaran juga menghambat guru dalam menyampaikan materi selanjutnya, pembelajaran yang seharusnya satu subtema dilaksanakan dalam waktu satu minggu menjadi lebih dari waktu dan memotong waktu pembelajaran materi selanjutnya.

Berkaitan dengan media pembelajaran, menurut Barroh dkk (2012: 5) buku berjendela adalah jenis buku yang berisi gambar-gambar dengan jendela yang dapat dibuka (bisa keatas, ke bawah, ke kanan, ke kiri) dan terdapat keterangan di baliknya. Berdasarkan pendapat tersebut diketahui bahwa media buku berjendela adalah media berbentuk buku yang terdapat lipatan-lipatan yang disebut jendela karena jika lipatan dibuka dan ditutup akan memberi informasi dan gambar yang akan memudahkan siswa dalam belajar dan meningkatkan minat belajar siswa. Sedangkan menurut Ainurohmah (2013: 2) mengatakan bahwa "pemilihan buku berjendela dalam penelitian ini juga memiliki karakteristik khusus berupa jendela yang memuat gambar-gambar yang dapat dibuka tutup layaknya jendela. Buku jendela membantu siswa dalam memahami pelajaran karena materi yang diuraikan lebih ringkas, jelas dan fokus sehingga materi lebih mudah dimengerti oleh siswa".

Melihat fakta yang dipaparkan diatas, peneliti membuat inovasi yang dapat meningkatkan minat belajar peserta didik, memudahkan peserta didik dalam memahami materi, dan mengefesiensikan waktu pembelajaran. Inovasi tersebut yaitu membuat media pembelajaran yang menarik dan dapat melibatkan keaktifan dan kefokusan peserta didik dalam pembelajaran seperti media budel (Buku Berjendela). Sehingga pembelajaran yang diterima oleh siswa menjadi bermakna dan siswa akan merasa sedang bermain, padahal dia sedang belajar.

Berdasarkan uraian yang telah dijabarkan, maka peneliti perlu melakukan pengembangan media budel (buku berjendela) pada tema keluargaku siswa kelas I Sekolah Dasar. Pengembangan media ini diharapkan dapat membantu guru dalam menyampaikan pembelajaran tematik terutama pada tema keluargaku di kelas I supaya pembelajaran lebih aktif, efektif, menyenangkan, dan dapat meningkatkan motivasi belajar peserta didik. 


\section{METODE PENELITIAN}

Jenis penilitian yang digunakan oleh penulis adalah penelitian dan pengembangan (Research and Development). Menurut Sugiyono (2017: 407) "Metode penelitian dan pengembangan atau dalam Bahasa Inggrisnya Reasearch and Development adalah metode penelitian yang digunakan untuk menghasilkan produk tertentu, dan menguji keefektifan produk tersebut". Sedangkan R\&D menurut Sukmadinata, Nana Syaodih (2016:164) adalah suatu proses atau langkah-langkah untuk mengembangkan suatu produk baru atau menyempurnakan produk yang telah ada, yang dapat dipertanggung jawabkan.

Peneliti memilih jenis penelitian berupa penelitian dan pengembangan (Research and Development) karena penulis mengembangkan produk berupa media pembelajaran. Media pembelajaran ini dikembangkan dari media buku berjendela yang sudah ada kemudian dijadikan alternatif media buku berjendela dengan inovasi yang baru tentunya melalui tahap pengujian terlebih dahulu.

Desain pengembangan media budel (buku berjendela) ini dilakukan berdasarkan tahapan langkahlangkah pengembangan yang dikemukakan oleh Sugiyono (2017: 408-427) yang terdiri dari beberapa langkah sebagai berikut: (1)Potensi dan masalah, (2) Mengumpulkan informasi, (3) Desain produk, (4) Validasi desain, (5) Perbaikan desain, (6) Uji coba produk, (7) Revisi Produk, (8) Uji coba pemakaian, (9) Revisi produk dan (10) Pembuatan produk masal.

Berdasarkan langkah-langkah penelitian tersebut, peneliti mengambil enam langkah dari sepuluh langkah-langkah penelitian. Proses penelitian ini yakni sebatas pada uji coba produk. Hal itu dilakukan karena adanya keterbatasan waktu, tenaga dan biaya. Adapun langkah-langkah penelitian pengembangan yang dilakukan oleh peneliti adalah sebagai berikut: potensi dan masalah, pengumpulan informasi, desain produk, validasi desain, perbaikan desain, uji coba produk, revisi produk(jika diperlukan), dan produk siap. Subyek penelitian ini adalah siswa kelas IA, IB, dan IC sekolah dasar di daerah kecamatan Semarang Selatan Kota Semarang. Sekolah dasar tersebut yaitu SD Negeri Peterongan.

Analisis data yang digunakan dalam penelitian ini yaitu analisis data kualitatif dan analisis data kuantitatif. Data kulitatif dalam penelitian ini yaitu berupa komentar dan saran perbaikan dari ahli media dan ahli materi pembelajaran. Data kuantitatif dalam penelitian ini berupa skor penilaian ahli media, ahli materi, respon guru dan siswa. Kedua data tersebut didapat dari pengisian angket. Data yang sudah terkumpul dianalisis dengan cara menghitung skor yang diperoleh. Analisis skor yang digunakan yaitu analisis deskriptif yang dianalisis menggunakan langkah-langkah sebagai berikut:

1) Penilaian angket kevalidan

Menganalisis data dari lembar angket dengan skala likert betuk checklist dilakukan langkahlangkah sebagai berikut:Langkah 1: Peneliti menghitung skoring setiap jawaban. Langkah 2 : Menghitung jumlah skor yang diperoleh dari penelitian. Langkah 3 : Menjumlahkan skor ideal item untuk seluruh item. Langkah 4 : Membagi jumlah total skor dengan skor ideal kemudian dikalikan $100 \%$.

Berdasarkan presentase yang telah diperoleh kemudian ditransformasikan ke dalam kalimat yang bersifat kuantitatif. Untuk menentukan kriteria dilakukan dengan cara yang dikemukakan Arikunto (2010: 44):

Tabel 1. Kriteria Skor Dikemukakan Arikunto

\begin{tabular}{rrc}
\hline \multicolumn{1}{l}{ No. } & Interval (\%) & Kriteria \\
\hline 1 & $81-100$ & Sangat Baik \\
2 & $61-80$ & Baik \\
3 & $41-60$ & Cukup \\
4 & $21-40$ & Kurang \\
5 & $0-20$ & Kurang Sekali \\
\hline
\end{tabular}

Untuk dapat memberikan makna dalam pengambilan keputusan, digunakan ketepatan sebagai indikator keberhasilan melalui validasi ahli media dan materi pembelajaran. Pada uji ahli media dan materi pembelajaran, hasil presentase tiap item dikatakan berhasil atau valid apabila hasil berada pada rentang 81\%-100\% dengan kriteria "sangat baik", rentang 61\%-80\% dengan kriteria "baik" atau rentang 41\%-60\% dengan kriteria "cukup".

\section{2) Penilaian angket kepraktisan}

Hasil respon guru dan siswa yang berupa nilai kuantitatif kemudian dihitung dan setelah mendapatkan hasil diubah menjadi kualitatif. Hal tersebut bertujuan untuk memperoleh nilai kualitas media budel (buku berjendela) berupa presentase keidealan dengan langkah-langkah sebagai berikut: a) Hasil penilaian tanggapan guru terhadap media budel (buku berjendela). Untuk menganalisi data 
penilaian tanggapan guru dengan menggunakan skala Likert dalam bentuk checklist, peneliti dapat melakukan perhitungan yang sama dengan cara penilaian angket kevalidan. b) Hasil penilaian respon siswa terhadap media budel (buku berjendela). Untuk menganalisis data penilaian respon siswa dengan menggunakan skala Guttman yang masih dalam bentuk huruf yaitu "tidak" dan "ya" diubah menjadi angka yang dapat dilihat didalam tabel dibawah ini:

Tabel 2. Pedoman Penskoran Angket Respon Siswa

\begin{tabular}{cc}
\hline Keterangan & Skor \\
\hline Tidak & 0 \\
Ya & 1 \\
\hline
\end{tabular}

Setelah data terkumpul, kemudian dianalisis dengan cara yang sama dengan skala Likert dengan menggunakan presentase sebagai berikut:

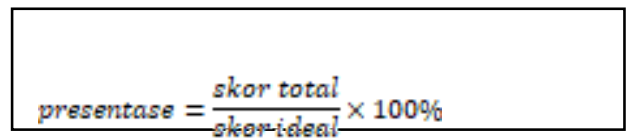

Hasil perhitungan presentaase menunjukkan tingkat keidealan media budel (buku berjendela) yang dihasilkan berdasarkan respon guru dan siswa kelas I sekolah dasar.

\section{ANALISIS DAN PEMBAHASAN}

Media pembelajaran budel (buku berjendela) dikembangkan peneliti berdasarkan langkah-langkah penelitian dan pengembangan (research and development). Peneliti menggunakan desain pengembangan yang di kemukakan oleh Sugiyono (2017: 408-427) yang terdiri dari beberapa langkah sebagai berikut: (1) Potensi dan masalah, (2) Mengumpulkan informasi, (3) Desain produk, (4) Validasi desain, (5) Perbaikan desain, (6) Uji coba produk, (7) Revisi Produk, (8) Uji coba pemakaian, (9) Revisi produk dan (10) Pembuatan produk masal. Berdasarkan sepuluh langkah tersebut, peneliti mengambil enam langkah dalam proses ini yakni hanya sebatas pada ujicoba produk.

Berikut adalah penjelasan dari modifikasi langkah pengembangan peneliti :1) Potensi dan Masalah, Peneliti mencoba mencari kemampuan yang dimiliki oleh siswa dan guru. Kemudian peneliti juga mencari permasalahan-permasalahan yang timbul ketika pembelajaran berlangsung sehingga mengakibatkan terhambatnya pembelajaran yang aktif, efektif dan menyenangkan. 2) Pengumpulan Informasi, Peneliti menemukan potensi dan masalah yang diambil dari wawancara guru kelas, hasil angket kebutuhan siswa guru kelas I SD Negeri Peterongan untuk mengetahui permasalahan yang ada dan untuk mengetahui pemecahan dari masalah tersebut yaitu dengan menggunakan media pembelajaran buku berjendela. 3) Desain Produk, Peneliti memulai pembuatan budel (buku berjendela) dengan membuat konsep terlebih dahulu. Setelah konsep jadi, peneliti melanjutkan mendesain konsep tersebut menggunakan aplikasi power point yang kemudian diubah formatnya menjadi png. Lalu, peneliti mencetak menggunakan kertas artcartoon 210. Setelah melakukan percetakan, maka peneliti melakukan pemotongan menggunakan cutter agar lebih rapi, dan dipotong sesuai konsep. Kemudian, peneliti juga memotong perekat sesuai konsep dan menempelkan pada kertas yang telah dibuat seperti jendela (dapat dibuka keatas, bawah, samping kanan dan kiri). Tahap terakhir yaitu menyatukan semua halaman yang telah dibuat seperti jendela dan perekat menjadi satu kesatuan layaknya buku.

1. Validasi Desain

Peneliti melakukan validasi desain dengan menggunakan media budel (buku berjendela) pada ahli media dan materi dan membagikan angket validasi ahli media dan materi untuk mengetahui tingkat kevalidan media budel (buku berjendela). Berikut adalah penjelasannya:

a. Hasil Validasi Ahli Media

Tahap validasi ahli media bertujuan untuk mengetahui kelayakan pembuatan produk media pembelajaran budel (buku berjendela) sebelum dilakukan uji coba lapanga awal. Pada tahap ini, peneliti memilih tiga validator sebagai validator ahli media yang merupakan dosen Pendidikan Guru Sekolah Dasar Universitas PGRI Semarang yaitu bapak Singgih Adhi Prasetyo, S. Sn., M.Pd, bapak Sukamto, S.Pd., M.Hum, dan ibu Anggun Dwi Setya Putri S.Pd., M.Pd. Validasi media dilakukan dengan memberikan lembar angket validasi ahli media. 
Maka dapat diperoleh hasil rata-rta presentase keidealan penilaian ahli media tahap pertama sebesar 79,55\% sehingga media budel (buku berjendela) termasuk dalam kriteria "baik". Namun, peneliti masih melakukan validasi tahap kedua untuk memperbaiki produk.

Setelah melakukan perbaikan yang telah disarankan oleh ahli materi kedua dan ketiga seperti memperbaiki cover dan background yang harus disesuaikan dengan tema 4 keluargaku dan memperbaiki bagian pembelajaran materi Pancasila untuk pemotongan katanya agar dapat dibaca secara jelas oleh siswa. Berikut adalah hasil analisis penilaian ahli media tahap kedua pada tabel 3.

Tabel 3. Hasil Validasi Ahli Media Tahap 2

\begin{tabular}{clcc}
\hline No & \multicolumn{1}{c}{ Ahli Media } & Presentasi Keidealan & Kriteria \\
\hline 1. & Sukamto, S.Pd., M.Pd. & $94,67 \%$ & Sangat Baik \\
2. & Anggun Dwi Setya Putri, S.Pd., M.Pd & $88 \%$ & Baik \\
\hline
\end{tabular}

Berdasarkan Tabel 3 maka dapat diperoleh hasil rata-rta presentase keidealan penilaian ahli media tahap kedua sebesar 91,34\% sehingga media budel (buku berjendela) termasuk dalam kriteria "sangat baik" dan dapat digunakan pada pembelajaran disekolah.

b. Hasil Validasi Ahli Materi

Tahap validasi ahli materi pembelajaran bertujuan untuk melihat sejauh mana materi yang ada pada media tersebut. Pada tahap ini, peneliti memilih tiga validator sebagai validator ahli materi yang merupakan dosen Pendidikan Guru Sekolah Dasar Universitas PGRI Semarang yaitu bapak Singgih Adhi Prasetyo, S. Sn., M.Pd, bapak Sukamto, S.Pd., M.Hum, dan ibu Anggun Dwi Setya Putri S.Pd., M.Pd. Validasi materi dilakukan dengan memberikan lembar angket validasi ahli materi. Berikut adalah hasil analisis penliaian dari ahli materi tahap pertama pada tabel 4.

Tabel 4. Hasil Validasi Ahli Materi Tahap 1.

\begin{tabular}{clcc}
\hline No & \multicolumn{1}{c}{ Ahli Media } & Presentasi Keidealan & Kriteria \\
\hline 1 & Singgih Adhi Prasetyo, S.Sn., M.Pd. & $85 \%$ & Sangat Baik \\
2 & Sukamto, S.Pd., M.Pd. & $85 \%$ & Sangat Baik \\
3 & Anggun Dwi Setya Putri, S.Pd., M.Pd & $73,33 \%$ & Baik \\
\hline
\end{tabular}

Berdasarkan Tabel 4. Maka dapat diperoleh hasil rata-rta presentase keidealan penilaian ahli media tahap pertama sebesar $81,11 \%$ sehingga media budel (buku berjendela) termasuk dalam kriteria "baik". Namun, peneliti masih melakukan validasi tahap kedua untuk memperbaiki produk.

Setelah melakukan perbaikan yang telah disarankan oleh ahli materi kedua dan ketiga seperti menambahkan petunjuk penggunaan media, dan memperbaiki pada materi matematika. Berikut adalah hasil analisis penilaian ahli materi tahap kedua pada Tabel 5.

Tabel 5. Hasil Validasi Ahli Materi Tahap 2.

\begin{tabular}{clcc}
\hline No & \multicolumn{1}{c}{ Ahli Media } & Presentasi Keidealan & Kriteria \\
\hline 1. & Sukamto, S.Pd., M.Pd. & $95 \%$ & Sangat Baik \\
2. & Anggun Dwi Setya Putri, S.Pd., M.Pd & $90 \%$ & Baik \\
\hline
\end{tabular}

Berdasarkan Tabel 5, maka dapat diperoleh hasil rata-rta presentase keidealan penilaian ahli media tahap kedua sebesar 92,50\% sehingga media budel (buku berjendela) termasuk dalam kriteria "sangat baik" dan dapat digunakan pada pembelajaran disekolah.

\section{Perbaikan Desain}

Perbaikan desain yang dilakukan peneliti, langkah-langkahnya sama ketika membuat desain produk. Perbedaannya ada pada aplikasi desain yang digunakan, kertas dan ukuran yang digunakan, serta isi dari setiap halaman yang direvisi. Peneliti merubah desain produk yang awalnya menggunakan powerpoint diganti dengan aplikasi coredraw $x 7$ agar tulisan dan gambar lebih jelas. Kertas yang digunakan yang awalnya artcartoon 210 diganti artcartoon 260 . Sedangkan ukuran yang awalnya 23 x 16 $\mathrm{cm}$ diganti menjadi $32 \times 23 \mathrm{~cm}$ agar lebih jelas gambar dan tulisan serta pemakaiannya. Isi dari setiap halaman diubah sesuai saran dari ahli media dan materi. 


\section{Uji Coba Produk}

Peneliti melakukan uji coba produk dengan menggunakan media budel (buku berjendela) pada pembelajarannya dan membagikan lembar angket respon siswa dan guru kelas I untuk mengetahui tingkat kepraktisan media budel (buku berjendela). Berikut adalah penjelasannya:

a.Hasil Respon Siswa

Media budel (buku berjendela) merupakan suatu hal baru yang diperoleh siswa. Hasil angket respon siswa bertujuan untuk mengetahui respon siswa terhadap keberterimaan media budel (buku berjendela) pada uji coba lapangan awal dengan dilakukan pengisian angket respon siswa kelas I di SDN Peterongan Semarang dan diperoleh hasil sebagai berikut :

Tabel 6. Hasil Respon Siswa

\begin{tabular}{cccc}
\hline No & Kelas & Presentasi Keidealan & Kriteria \\
\hline 1. & IA & $98,46 \%$ & Sangat Baik \\
2. & IB & $89,33 \%$ & Sangat Baik \\
3. & IC & $90,67 \%$ & Baik \\
\hline
\end{tabular}

Berdasarkan tabel 4.23. Maka dapat diperoleh hasil rata-rta presentase keidealan penilaian respon siswa sebesar 92,82\% sehingga media budel (buku berjendela) termasuk dalam kriteria "sangat baik".

b. Hasil Respon Guru

Hasil angket respon guru kelas bertujuan untuk mengetahui respon guru kelas terhadap kelayakan media budel (buku berjendela) pada uji coba lapangan awal dengan dilakukan pengisian angket respon guru kelas IA, IB dan IC di SDN Peterongan Semarang serta diperoleh hasil sebagai berikut :

Tabel 7. Hasil Respon Guru

\begin{tabular}{cccc}
\hline No & Kelas & Presentasi Keidealan & Kriteria \\
\hline 1. & IA & $94 \%$ & Sangat Baik \\
2. & IB & $88 \%$ & Baik \\
3. & IC & $90 \%$ & Sangat Baik \\
\hline
\end{tabular}

Berdasarkan tabel 4.22. Maka dapat diperoleh hasil rata-rta presentase keidealan penilaian respon guru sebesar 90,67\% sehingga media budel (buku berjendela) termasuk dalam kriteria "sangat baik" dan dapat digunakan pada pembelajaran disekolah.

4. Revisi Produk

Revisi Produk tidak diperlukan peneliti karena dalam uji coba produk, produk dikatakan praktis dan tidak memerlukan revisi lagi.

\section{Produk Siap}

Media budel (buku berjendela) telah siap dan dapat digunakan menjadi media alternative ketika mengajar yang dapat membantu peserta didik dalam memahami materi pada tema 4 keluargaku subtema 1 anggota keluargaku dan membantu guru untuk menyampaikan pembelajaran di kelas.

\section{KESIMPULAN}

Media pembelajaran budel (buku berjendela) pada tema keluargaku subtema anggota keluargaku siswa kelas I SD Negeri Peterongan, dikembangkan dalam bentuk buku yang dilengkapi dengan gambar yang dapat dibuka seperti jendela dan perekat yang dapat dipasang dan dilepas. Langkah-langkah pengembangan yang diambil peneliti menurut Sugiyono (2017:408-427) yaitu sampai tahap keenam, uji coba produk. Peneliti memodifikasi 6 tahap tersebut menjadi beberapa tahapan yaitu: potensi dan masalah, pengumpulan informasi, desain produk, validasi desain, perbaikan desain, uji coba produk, revisi produk (jika ada), dan produk siap.

Setelah melalui tahap pencarian potensi dan masalah, pengumpulan informasi hingga membuat desain produk, kemudian peneliti melakukan uji validasi desain dan perbaikan desain sehingga media budel (buku berjendela) dinyatakan valid dengan mendapatkan skor rata-rata presentase keidealan dari ahli media sebesar 91,34\% dengan kriteria "sangat baik", dan mendapatkan skor rata-rata presentase keidealan ahli materi dengan rata-rata sebesar 92,80\% dengan kriteria "sangat baik". Sedangkan ketika uji coba produk, media budel (buku berjendela) dinyatakan praktis digunakan pada tema keluargaku kelas I sekolah dasar dengan mendapatkan skor rata-rata presentase keidealan hasil respon guru sebesar $90,67 \%$ dengan kriteria "sangat baik" dan dari skor rata-rata presentase keidealan hasil respon siswa 
sebesar 92,82\% dengan kriteria "sangat baik" serta tidak adanya revisi produk. Oleh karena itu, dapat disimpulkan bahwa media budel (buku berjendela) valid dan praktis untuk digunakan siswa kelas I tema keluargaku, subtema anggota keluargaku.

Dari hasil penelitian, maka saran yang dapat diajukan adalah sebagai berikut : 1)Bagi guru, penggunaan media dalam pembelajaran dapat digunakan oleh guru untuk meningkatkan tingkat kefokusan siswa pada pembelajaran sehingga siswa menjadi senang dan antusias mengikuti pembelajaran serta dapat mengefektifkan waktu supaya tidak membutuhkan waktu yang lama dalam mengajar tematik. 2) Bagi sekolah, pihak sekolah sebaiknya memberi fasilitas terhadap guru yang memiliki kreativitas dalam mengembangkan sebuah media pembelajaran untuk menunjang kebutuhan siswa dalam pembelajaran. 3) Bagi peneliti, peneliti menyadari bahwa penelitian dan pengembangan ini belum sempurna, maka diharapkan dilakukan penelitian pengembangan selanjutnya di kemudian hari guna menyempurnakan penelitian ini dan menjadi produk baru dalam penelitian pengembangan tentang media pembelajaran.

\section{DAFTAR PUSTAKA}

Ainurrohmah Resfita. 2013. "Pengembangan Perangkat Pembelajaran dengan Buku Berjendela Pada Materi Gejala-Gejala Atmosfer Kelas VII di SMPN 3 Balong panggang Gresik". http://jurnalmahasiswa.unesa.ac.id/index.php/swarabhumi/article/view/3977. Diakses ada tanggal 04 oktober 2017.

Arikunto, Suharsimi. 2010. Manajemen Penelitian. Jakarta: Rineka Cipta.

Anglada, D. 2007. An Introduction to Instructional Design: Utilizing a Basic Design Model. (Online) melalui http://www.pace.sdu/ctlt/newsletter, diakses 17 Januari 2014.

Ariana, Monica. (2012). Mind Mapping And Brainstorming As Methods Of Teaching Business Concepts In English As A Foreign Language. Academica Science Journal Psychologica Series. No. 1. 2012

Azhar Arsyad. (2013). Media Pembelajaran. Jakarta: Raja Grafindo Persada.

Barroh Habibbatul, Endang Susantini, Ducha Nur. 2012. "Pengembangan Buku Ajar Berjendela pada Materi Sistem Reproduksi Manusia untuk SMP RSBI". E-journal Unesa Vol 1 no 22012. http://jurnalmahasiswa.unesa.ac.id/article/792/34/article.pdf. Diakses pada 15 Desember 2017.

Buzan, Tony. 2007. Buku Pintar Mind Mapping. Jakarta: Gramedia Pustaka Utama, Jakarta.

Darusman, Rijal. (2014). Penerapan Metode Mind Mapping (Peta Pikiran) Untuk Meningkatkan Kemampuan Berpikir Kreatif Matematik Siswa SMP. Jurnal Ilmiah Program Studi Matematika STKIP Siliwangi Bandung. Vol.3 No.2

Dhey, michael and branch, robert maribe. 2009. Educational Media and Techology Year book. Newyork: Springer

Jensen. Eric dan Karen Makowitz. 2002. Otak Sejuta Gygabite: Buku Pintar Membangun Ingatan Super. Bandung: Kaifa.

Koyan, 2012. Statistik Pendidikan Teknik Analisis Data Kuantitatif. Undiksha.

Kustandi, Cecep dan Sutjipto,Bambang. 2011. Media Pembelajaran Manual dan Digital. Jakarta: Ghalia Indonesia.

Prayudi: 2008. Pengaruh Penggunaan Strategi Pembelajaran Mind Mapping terhadap Prestasi belajar.jakarta.

Peraturan Menteri Pendidikan Nasional Republik Indonesia Nomor 22 Tahun 2006 tentang Standar Isi Untuk Satuan Pendidikan Dasar dan Menengah. 2006. Jakarta. Menteri Pendidikan Nasional Republik Indonesia. 
Riyanto, Yatim. 2010. Paradigma Baru Pembelajaran. Jakarta: Kencana Pernada Group.

Sanaky, Hujair AH. 2013. Media Pembelajaran Interaktif-Inofatif. Yogyakarta: Kaukaba Dipantara.

Sugiyono. 2017. Metode Penelitian Pendidikan: Kuantitatif, Kualitatif, R@D. Bandung: Alfabeta.

Sukmadinata, Nana Syaodih. 2016. Metode Penelitian Pendidikan. Bandung: PT Remaja Rosdakarya.

Suyatno. 2009. Menjelajah Pembelajaran Inovatif. Sidoarjo: Masmedia Buana Pustaka.

Trianto. 2010. Pengembangan Model Pembelajaran Tematik. Jakarta: PT Prestasi Pustakaraya.

Triono Adil, dkk. (2006) Pedoman Pengembangan Media Pembelajaran Pendidikan dan Pelatihan Pendidikan Non-Formal. Jakarta: Depdiknas.

Undang-undang Dasar Negara Republik Indonesia No.20 Tahun 2003 Pasal 1 ayat 1 tentang Sistem Pendidikan Nasional.

Yildirm, Zahide. 2007. Instructional Media and Technologies for Learning. New Jersey: Merril Prentice hall.

Zampetakis, Leonidas A and Tsironis, Loukas. (2007). "Creativity development in engineering education: the case of mind mapping”. Journal of Management Development. Vol. 26 No. 4, pp. 370-380. 